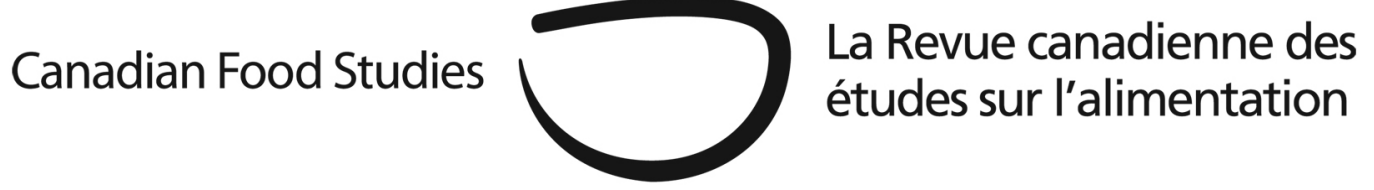

\title{
Land grabbing and land concentration: Mapping changing patterns of farmland ownership in three rural municipalities in Saskatchewan, Canada
}

\author{
Annette Aurélie Desmarais, ${ }^{1}$ Darrin Qualman, ${ }^{2}$ André Magnan, ${ }^{3}$ and Nettie \\ Wiebe $^{4}$ \\ 1 Canada Research Chair in Human Rights, Social Justice and Food Sovereignty, University of \\ Manitoba (corresponding author: annette.desmarais@umanitoba.ca) \\ 2 Former researcher and Executive Director, National Farmers Union \\ ${ }^{3}$ Associate Professor, Department of Sociology and Social Studies, University of Regina \\ 4 Professor, St. Andrews College, University of Saskatchewan
}

\section{Abstract}

Since the 2007-08 global food crisis there is growing interest in changing patterns of farmland ownership. Using a dataset of the names of all farmland titleholders along with GIS data mapping software, this article demonstrates changes in patterns of land ownership in three rural municipalities (RMs) in Saskatchewan, Canada. A diverse mix of new actors have entered the farmland market in the past decade or two, with some now owning more than 100,000 acres each in the province. Our research reveals a list of the investment companies, pension plans, and large farmer/investor hybrids buying land; it also maps investment activity and large land transactions in the three RMs. While $7.8 \%$ to $13.1 \%$ of the farmland is now owned by "land grabbers," our study also found a significant rise in land concentration in the hands of farmers when compared to twenty years ago. For example, in one RM, the four largest landowners-a mix of farmers and investment companies and farmer/investor hybrids-now own $28 \%$ of the land. This article also discusses some initial findings concerning the impact that changing patterns of land ownership 
are having on the cohesion and vitality of communities and concludes with a series of questions for further research.

\section{Introduction}

In recent years, there has been growing academic, civil-society, and public interest in changing patterns of farmland ownership in agricultural sectors around the world. These changes are part and parcel of the ongoing restructuring of the global food system under the corporate food regime (McMichael, 2012). While this transformation arguably began in the 1980s with the globalization of a variety of important agri-food sectors, it has accelerated since the global food crisis of 2007-08. The dominant trends in the corporate food regime are the increasing concentration of power and resources in the hands of agribusiness firms and financial interests, the marginalization of small farmers, and global market volatility. It is in this context that a range of important transformations has occurred in patterns of farmland ownership. In particular, there is growing attention being paid to large-scale farmland purchases involving sovereign wealth funds, agribusiness corporations, hedge funds, pensions, and other actors, especially since the food crisis. Referred to by critics as the global "land grab" (GRAIN, 2008), these transactions raise many questions about the changing dynamics of farmland ownership and control including: the power dynamics between farmland owners and tenants/workers; the motives and decisionmaking horizons of investors compared to family-farm landowners; environmental questions related to land use, soil, water, and biodiversity; and the implications for rural communities, control over food production, food security, and food sovereignty.

This article examines changing patterns of farmland ownership in three rural municipalities (RMs) ${ }^{1}$ in Saskatchewan, Canada. Since the mid-2000s, a range of new actorsincluding farmland investment firms, pension funds, and family-based and corporate megafarms - have acquired large tracts of farmland in the province (Sommerville \& Magnan, 2015; Sommerville, 2013; Magnan, 2012; NFU, 2010). While previous studies have identified some of the key players and begun to analyze the implications of these changes in farmland ownership, we provide a more fine-grained analysis of the geographical patterns of changing farmland ownership. Specifically, we use geographical information systems (GIS) and land titles data to identify the largest landowners and to calculate the degree of concentration in land ownership in these three RMs. In addition, we provide a comparison of land ownership in 1994 and 2014, highlighting the extent of the changes that have occurred over the intervening twenty years.

The article is organized as follows. In the next section, we provide some theoretical and empirical context by briefly reviewing the literature on the global land grab, the financialization of farmland, and the restructuring of the prairie agricultural sector. Next, we explain the research methodology and its applicability to understanding patterns of farmland ownership and

\footnotetext{
${ }^{1}$ Saskatchewan's agricultural region—roughly the southernmost 40\% of the province—is divided into 296 administrative units called Rural Municipalities (RMs).
} 
concentration. This is followed by a discussion of the key empirical findings, including the identity of the largest landowners, rates of ownership concentration, and historical patterns. We then explain some initial findings concerning the impact that changing patterns of land ownership is having on the cohesion and vitality of rural communities. We conclude by raising a number of questions for further research.

\section{Context: Twenty-first century land politics}

There is a growing academic and civil-society literature on the twenty-first century global land grab (White, Borras, Hall, Scoones \& Woolford, 2012; Cotula, 2012; De Schutter, 2010 and 2011; GRAIN, 2008, 2014; Margulis, McKeon \& Borras, 2013; Murmis \& Murmis, 2012; Pearce, 2012; La Vía Campesina, 2013; Wolford, 2010; Zoomers, 2010). Well-known journalssuch as the Journal of Peasant Studies (2011 and 2012), Globalizations (2013), Third World Quarterly (2013), and Development and Change (2013)—-have all published special editions that examine different elements of land grabbing, primarily in the global South. To date, the literature has focused primarily on conceptualizing land grabbing, understanding the scale and scope of the phenomenon, and explaining its key drivers. While an exhaustive review of the literature is beyond the scope of this paper, we highlight some of the key conceptual, political, methodological, and empirical issues raised by other scholars.

Broadly speaking, "land grabbing” refers to the twenty-first century phenomenon wherein large tracts of farmland are bought up by investment funds, corporations, pension funds, sovereign wealth funds, and other private interests. While many cases involve land purchases, in others some of the same interests gain control over farmland through long-term leases. The term "global land grab” was pioneered by the civil-society organization GRAIN, which has maintained a large web-based repository of news reports on large-scale land deals for several years (farmlandgrab.org). The term deliberately politicizes large-scale land deals as a way of underlining their potential for dispossessing marginalized groups including small-scale farmers, pastoralists, and indigenous peoples.

In the face of civil-society criticism, there have been some international initiatives to regulate large-scale land deals. Some of the largest farmland investors have designed a set of voluntary "principles for responsible investment in farmland" that include commitments for "promoting environmental sustainability, respecting labour and human rights, respecting existing land and resource rights, upholding high business and ethical standards, and reporting on activities and progress towards implementing and promoting the Principles” (PRI, 2014). Meanwhile, UNCTAD, the FAO, IFAD, and the World Bank have developed a similar set of principles, with many of the same provisions, along with commitments to ensure that investments do not compromise, but rather improve food security, and lead to "desirable social and distributional impacts" (UNCTAD, 2014). These voluntary safeguards have been rejected by civil society critics such as GRAIN as a weak set of standards designed to provide a veneer of 
social responsibility to land grabbing (GRAIN, 2012), and by scholars for failing to question the underlying assumptions of the land rush as well as its causes (White et al., 2012).

While the processes, politics, and consequences of large-scale land deals vary tremendously across social and geographical contexts, the common thread is a transfer of ownership and control of land and resources away from local communities and actors towards financial capital and corporate interests. Although most of the land grabbing literature has focused on the global South, recent publications have applied the concept to changing patterns of farmland ownership in Western Europe (Franco \& Borras, 2013), Québec (L’Italien, 2012), and the U.S (Ross \& Mittal, 2014). In the global North, large-scale land deals do not involve the same sort of overt dispossession and human rights abuses, and do not necessarily lead to significant changes in land use or production systems, as has been the case in land grabs occurring in the global South. Indeed, the trends documented in this article involve "willing sellers" and "willing buyers" in a capitalist land market. However, these transactions are made in a highly unequal playing field in which some actors (investors with tens or hundreds of millions of dollars at their disposal) have considerably more resources than others (family farmers). Furthermore, as Sommerville \& Magnan (2015) have argued, farmland buy-ups in places such as Canada are intimately connected to the neoliberal restructuring of the agricultural sector, which has concentrated power and resources in fewer hands. Specifically, the entry of new actors changes the political and economic dynamics of access to and control of farmland, with consequences for family farms of different scales, rural communities, and younger farmers, as discussed below. We therefore use "land grabbing” as a conceptual framework for problematizing the increasingly unequal resources and power of different actors in the market.

According to Cotula (2012), there are a number of complex global drivers of the recent spate of large-scale land deals. First, growing demand for agricultural commodities, including grain for biofuels, ${ }^{2}$ has contributed to high food prices and made farmland and primary production more attractive to capital. Second, a range of financial actors have invested large sums in the food and agriculture sectors as a means of mitigating risk, diversifying their portfolios and achieving higher returns, a phenomenon referred to as the "financialization" of agriculture. This trend was, at least in part, a reaction to the global financial crisis of 2007-08, which led investors to seek profit-making opportunities from high food prices, food price volatility, and rising land prices. Third, governments have played an important role, as target countries encourage large-scale investment in their agricultural sectors and investor countries launch new projects to improve their food security by off-shoring the production of key commodities.

A number of other scholars have linked growing investor interest in farmland with the financialization of the agri-food and natural resource sectors (Burch \& Lawrence, 2009; Fairbairn, 2014; Gunnoe, 2014). Financialization is occurring at many different links along the

\footnotetext{
${ }^{2}$ Demand for biofuels has become less important in recent years as new oil production, particularly U.S. shale oil, has contributed to lower energy prices. With higher domestic oil production, biofuels are also becoming less important to the American strategy of energy self-sufficiency.
} 
agri-food chain, including farm inputs, food processing, the global food commodities trade, as well as farmland (Isakson, 2014; Clapp, 2014). Investment firms tout farmland as a highperforming investment, an inflation hedge, a portfolio diversification option, a risk management tool, even "gold with yield"-a phrase used by some farmland investment advocates, including Agcapita Farmland Investment Partnership, one of Canada's largest farmland investment funds (Agcapita, 2009; Fairbairn, 2014). As Fairbairn (2014) has argued, "the current wave of farmland investment combines a renewed interest in productive, real assets with an underlying adherence to the logic of financialization” (p. 779). Although some financial analysts and investors consider farmland investment a return to "real" as opposed to "speculative" investments (like derivatives), there is clearly a speculative dimension to this trend. Investors treat farmland as a financial asset to the extent that they are banking on capital appreciation as a source of profits. The expectation of capital appreciation is in turn a bet on rising food commodity prices, driven by macro trends such as increased global demand for food, fuel, and fibre. The speculative dimension of farmland investment is particularly evident in the "own lease-out" model, described below, where investors assume no exposure to production risks (or rewards), but simply hold the assets in anticipation of rising land prices (ibid., p. 786).

It is in this context that a range of entities has, since the mid-2000s, begun to buy large tracts of Saskatchewan farmland. Sommerville and Magnan (2015) have documented the emergence of a number of farmland investment firms (FIFs), whose core business is to build a portfolio of land on behalf of investors, then rent out the land to independent farm operators. These firms have amassed several hundred thousand acres of land worth hundreds of millions of dollars. In early 2014, one of the key FIFs, Assiniboia Farmland Limited Partnership, sold its entire portfolio to the Canadian Pension Plan Investment Board for \$128 million; Assiniboia continues to manage this portfolio on behalf of its new owner (CCPIB, 2013). The FIFs are motivated both by the prospect of capital gains from rising land prices and the steady income provided through leases.

Other large-scale buyers, which we call farmer/investor hybrids, are private individuals such as Cor Van Raay, or corporate farming entities such as Nil-Ray Farms Ltd., part of a conglomerate of agri- and other businesses that, until recently, included one of Canada's largest beef packing plants and may still include several cattle auction marts. ${ }^{3}$ Less is known about these private buyers than the FIFs; for instance, it is unclear whether they directly manage agricultural production on their land or rent it out to others. They nonetheless are accumulating large landholdings, may have few or no ties to the local community, and are therefore considered alongside other outside farmland buyers. The Players section of this article provides more information on the farmer/investor hybrid category.

\footnotetext{
${ }^{3}$ Nilsson Bros. sold its XL food plant in Brooks, Alberta to the Brazilian JBS in 2012.
} 


\section{Saskatchewan farmland: Policy, economic and demographic changes}

There are several reasons why Saskatchewan farmland has become particularly attractive to investors of different stripes. To begin with, Saskatchewan liberalized its farmland ownership laws in 2002 by amending the Saskatchewan Farm Security Act. Until that year, ownership of Saskatchewan farmland was restricted to Saskatchewan citizens and Saskatchewan-owned agricultural corporations (Ferguson \& Furtan, 2006). Legislation in 2002 expanded ownership provisions to all Canadian citizens and to certain classes of Canadian-owned corporations. In announcing the legislation, the provincial government indicated that the changes were intended to send the message to all Canadians that "Saskatchewan is open to outside investment" (Government of Saskatchewan, 2002). This policy change triggered a great deal of investor interest in Saskatchewan farmland (Hursh, 2010), in part because some believed that the previous restrictions had kept provincial land prices artificially low. Indeed, Saskatchewan farmland values have historically been lower than those of neighbouring provinces and are still much lower than farmland prices in other countries. According to Savills (2012), the average price of Saskatchewan farmland in 2011 was US\$650/acre compared to nearly US\$3,035/acre in the US and US\$9,025/acre in the UK. ${ }^{4}$ In recent years, Saskatchewan farmland values have been increasing considerably and are "catching up" to those in the other Prairie provinces. Between 2007 and 2013, average farmland values increased by 109\% (FCC, 2013). Investors are also drawn to Saskatchewan for its abundance of high quality farmland, industrialized farming sector, modern infrastructure, and stable legal and political environment (Sommerville \& Magnan, 2015).

The large-scale transfer of farmland to new investors is occurring in the context of the ongoing restructuring of the prairie agricultural sector. There has been a significant reorientation of agricultural policy and market structures as successive governments have embraced neoliberalism since the 1980s (Knuttila, 2003). This reorientation has involved the implementation of "free trade" agreements such as NAFTA and the WTO, cuts to or the elimination of key farm programs, the elimination of grain transportation subsidies (the Crow Benefit), repeated overhauls of farm income stabilization programs, the privatization of farmerowned grain handling cooperatives (the Saskatchewan Wheat Pool, and similar cooperatives in neighbouring provinces), and the elimination of single-desk wheat and barley marketing through the Canadian Wheat Board (for the latter, see Magnan, 2014). These changes generally eroded economic conditions for family farms, even as farm productivity, output, and export volumes increased steadily (Wiebe, 2012).

The agricultural sector in Canada has undergone a process of continual consolidation for many decades, as farm families exit the sector and remaining farms get larger, an issue to which we return below. The result is a sector in which a small number of very large farms account for the bulk of production, but which is still subject to a great deal of volatility. Low net farm incomes have plagued farmers in Saskatchewan and Canada for much of the past three decades

\footnotetext{
${ }^{4}$ These figures were converted to US\$/hectare by the authors.
} 
(Figure 1). Many farm families have had to rely on off-farm income, government assistance, net worth drawdown, and borrowed money in order to supplement their inadequate farming incomes. As a result, farm debt has reached record levels: $\$ 78$ billion in Canada in 2013; $\$ 10.7$ billion in Saskatchewan - up $60 \%$ over the past 10 years and continuing to rise. ${ }^{5}$ While net incomes since 2008 have been much better, weakened financial conditions, overhanging debt loads, rapidly rising land prices, competition from non-farmers, and continued uncertainty make it difficult for many farmers to buy land.

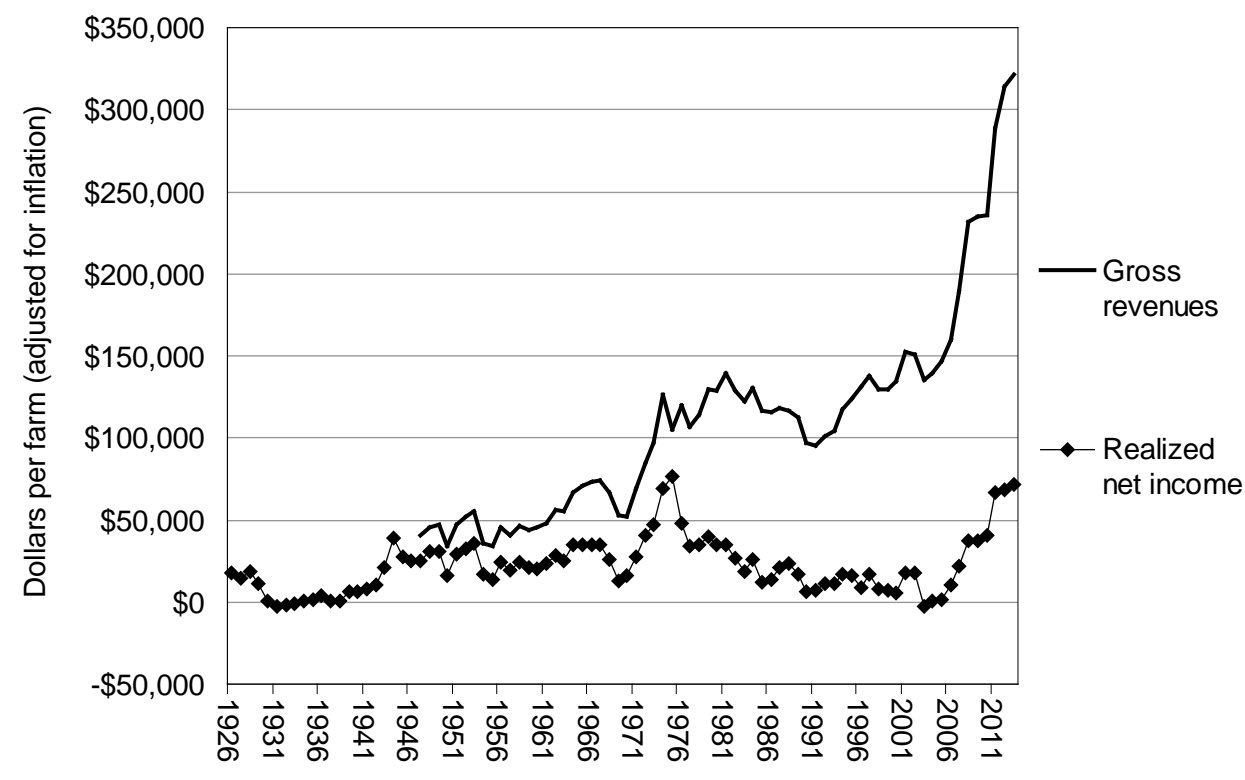

Figure 1.

Saskatchewan gross farm revenues and net farm income, 19262013, per farm average, adjusted for inflation. Realized net farm income is the money that farms have left over after all bills and expenses are paid, but before any payments are made to farm family members for their labour and management. Sources: 1926-2012: Stats. Can. CANSIM Tables 0020001 and 002-0009; 2013 (AAFC 2014).

At the same time, demographic and social changes are affecting the process of intergenerational transfer. Farm operators are getting older and many are nearing retirement age. Further, low net farm incomes combined with good off-farm job prospects for young people in Saskatchewan mean that, on many family farms, the generation that would otherwise take over the operation has left to work elsewhere-often in cities. As a result, retiring farmers may sell their land to neighbouring farmers or other buyers, including investors, interrupting the process of intergenerational transfer and contributing to the consolidation of land holdings. With rising land prices in recent years, the prospect of selling land and retiring can be very enticing for older farmers. By contrast, high land prices pose a barrier to entry for anyone wishing to enter farming, especially young farmers and new farmers.

These conditions have played a role in the emergence of new models of farmland ownership and investment (Sommerville \& Magnan, 2015). For instance, some of the farmland investment firms partner with farmers who want to expand their land base, but without taking on any additional debt. In these cases, the investment firm will purchase land identified by the farmer and lease it to them, allowing them to optimize the use of their labour and/or machinery.

\footnotetext{
${ }^{5}$ Statistics Canada, CANSIM Table 002-0008, Farm debt outstanding, classified by lender.
} 
This contributes to the further consolidation of agricultural production under fewer operators. In other cases, investment firms argue that they may be facilitating a different form of farm "succession," as they buy out retiring farmers and lease the land to the farm family's next generation. The idea is that this allows the younger generation, who may not be able to afford to purchase the land, to continue farming and gradually buy back into the farm. ${ }^{6}$ In short, the financialization of prairie agriculture is both a response to and an extension of the restructuring of the sector under neoliberalism.

We do not wish to suggest that all instances of farmland concentration constitute "land grabbing." Rather, we posit that there is a complex relationship between the ongoing concentration of ownership and control over agricultural resources and the entry of new actorsthe "land grabbers." These trends may reinforce one another as more concentrated landholdings become appealing targets for outside investment, and also as the new actors become large landowners.

Previous research has identified some of the macro trends driving changing patterns of farmland ownership, as well as some of the strategies and motivations of the new farmland owners. However, to our knowledge no study to date has examined in detail the nature and extent of ownership change in a particular geographic location in Canada. We address this gap by providing a fine-grained analysis of farmland ownership change in three Saskatchewan RMs. In the next section, we describe the methodology developed to track these changes.

\section{Methodology}

In Canada, governments do not publish data in formats that can be used to identify or quantify shifts in farmland ownership. Instead, published data is highly aggregated and makes little distinction between, for instance, land owned by farm families and that owned by highlycapitalized investment funds. Because of this, there is little information and few reports available to the public or policy makers on farmland ownership concentration or other shifts in ownership patterns in Canada. There do exist, however, comprehensive and fine-grained raw data on land ownership: land titles records that list the owners, size, and location of every parcel in a given province. We use this detailed data, coupled with geographic information systems (GIS) mapping software and other analytic programs, to analyze shifts in farmland ownership in three rural municipalities (RMs) in Saskatchewan, Canada. ${ }^{7}$

\footnotetext{
${ }^{6}$ To what extent this is a desired form of farm succession can certainly be questioned, but it may help explain the appeal of land sales in some circumstances. Among some of the most important concerns are the following: first, if the younger generation actually succeeds in re-purchasing the land it is not at all guaranteed that ownership would remain in the hands of the family over generations as is more common with a successful farm succession process; second, there is also the question of whether or not the younger generation has simply been forced out of the market due to rapidly rising and high land prices.

${ }^{7}$ Other researchers have used similar methodologies to study changing land ownership patterns in other jurisdictions. An excellent example is Pritchard et al.’s (2012) complex and comprehensive study of rural Australia.
} 
We obtained a dataset of all the land titles in the agricultural region of the province of Saskatchewan (Figure 2) from Information Service Corporation (ISC)—a public-private partnership 31\% owned by Saskatchewan's government. That dataset includes the name(s) of the owner(s) of each title. Analysis of this data, and similar data available free to the public at ISC's website, allowed us to begin to assemble a list of investors, investment funds, pension plans, farmer/investor hybrids, large farmers, and other highly capitalized entities that own large areas of Saskatchewan farmland. To expand this list and better understand who was buying up land, we sent inquiries to approximately forty farmers and rural residents across the province. ${ }^{8}$ The names and contact information for those people were obtained from a farm organization, the National Farmers Union, and many people contacted are members of that organization. We asked these rural residents to look over recent maps of their RMs and surrounding RMs and send back lists of landowner names they saw on those maps that were, or appeared to be, investment companies, numbered companies, and other owners whose names the local residents did not recognize and who own large areas of farmland. The names provided by these rural residents were further researched through corporate registries and online sources. Finally, we drew on media reports and academic journal articles to ascertain additional names of investment funds and other non-farmers buying farmland.

Utilizing the corporate registries in four provinces, media reports, company websites, and other public sources, we refined our list of the major entities buying farmland. Clearly, no such list can be complete: farmland investment is non-reported and non-transparent and it is not possible to research every landowner. More specifically, it is not possible to identify individuals who may have purchased 1,000 or 2,000 acres as an investment. Nonetheless, the lists we have assembled include most of the large investor entities (holdings over 10,000 acres) and, given the comprehensiveness and detail of our dataset, our list is probably more complete than previous lists, or lists from other jurisdictions. This article demonstrates that, where public land-title datasets can be obtained, it is possible to conduct detailed studies of land grabbing, concentration, and other changes in patterns of land ownership and control.

Next, we analyzed ownership patterns in the province's 296 rural municipalities to find RMs where investment companies and similar entities were active. We selected three RMs as our focus: RM 71, Excel, southwest of Regina; RM 128, Lajord, southeast of Regina; and RM 316, Harris, southwest of Saskatoon (Figure 2). Our selections were based on two criteria: the portion of land in the RM owned by investment companies and similar entities; and the diversity of the investment companies and other large entities represented within the three RMs. Our aim was not to profile average or randomly chosen RMs, but rather to focus on RMs where large shifts are occurring and where a diverse cross-section of buyers are active so that we can best illustrate the changes underway and the large entities driving those changes. Our larger analysis of the landowner database for the entire agriculture region of the province reveals that our three chosen RMs are not exceptional; rather, they are representative of dozens of RMs. Our

\footnotetext{
${ }^{8}$ Pritchard et al. (2012) point out that others have successfully used local informants in studies of landownership patterns as a way to triangulate the information provided by land titles.
} 
analysis of the titleholder dataset continues, and will form the basis for a province-wide analysis in an upcoming article.

Table 1 lists the physical and population characteristics of the three RMs. Figure 2 (see page 25) shows the locations of these RMs within the province of Saskatchewan.

\begin{tabular}{lrrrrrr}
\hline & $\begin{array}{l}\text { Area of RM } \\
\text { (square kms) }\end{array}$ & $\begin{array}{l}\text { Area of RM } \\
\text { (acres) }\end{array}$ & $\begin{array}{l}\text { Area of farms } \\
\text { (acres) }\end{array}$ & $\begin{array}{l}\text { Pop., 2011 } \\
\text { (persons) }\end{array}$ & $\begin{array}{l}\text { Pop., 1991 } \\
\text { (persons) }\end{array}$ & $\begin{array}{l}\text { Pop. change, } \\
1991 \text { to 2011 } \\
\text { (percent) }\end{array}$ \\
\hline RM 71, Excel & 1,122 & 277,258 & 263,034 & 427 & 630 & $-32 \%$ \\
\hline RM 128, Lajord & 944 & 233,235 & 205,133 & 993 & 1,032 & $-4 \%$ \\
\hline RM 316, Harris & 805 & 199,024 & 134,897 & 224 & 295 & $-24 \%$ \\
\hline Average for 3 RMs & 957 & 236,479 & 201,121 & 548 & 652 & $-16 \%$ \\
\hline All Sask. RMs, total & 307,847 & $76,070,650$ & $61,628,148$ & 147,585 & 209,923 & $-30 \%$ \\
\hline
\end{tabular}

Table 1. Characteristics of selected rural municipalities. Data sources: area of RMs: Statistics Canada 2011b; area of farms: Statistics Canada 2011a; population in 2011: Saskatchewan Bureau of Statistics 2012; population in 1991: Saskatchewan Bureau of Statistics 2006.

To reveal the shifts in farmland ownership, we compared the current situation to a time in the past: the year 1994. We selected that year for several reasons. The twenty-year span between 1994 and 2014 includes the 2003 deregulation of farmland ownership in Saskatchewan (see Context section, above). The 1994 to 2014 span also encompasses the commodity and real estate booms of the 2000s. Also, 1994 was the year the North American Free Trade Agreement (NAFTA) was implemented in Canada, the US, and Mexico, accelerating a range of changes in agriculture and all sectors of the economy. Although 1994 is our comparative year, it was not possible in every case to have access to land ownership data for that year. Such data were obtained from archived maps of the three RMs. In cases where the selected RMs did not produce updated maps in 1994, we chose a year that was as close as possible. Comparative data is therefore taken from maps updated in 1996 for RM 71; late 1993 for RM 128; and 1994 for RM 316. Since the land-title data were not available in digital format, we interviewed long-term residents in the area who had direct experience with their rural municipal office, either as a municipal reeve, administrator, or municipal council member, and systematically went over these 1990s maps to identify title holders. We were confident in using the methodology of oral history in these cases since those interviewed were not only long-time members of the community but in their public roles they were also responsible for being informed and/or documenting changes in land tenure in their municipality. There is a long history of growing trust in oral history demonstrated in both historical and anthropological research. Especially when using the practice of “sparking techniques” (i.e., visuals such as maps), memory has often proven to be remarkably informative and accurate. Our experience, then, supports arguments about the reliability of oral testimony and memory that has long been debated. ${ }^{9}$

\footnotetext{
${ }^{9}$ See, for example, the journal Oral History Review.
} 


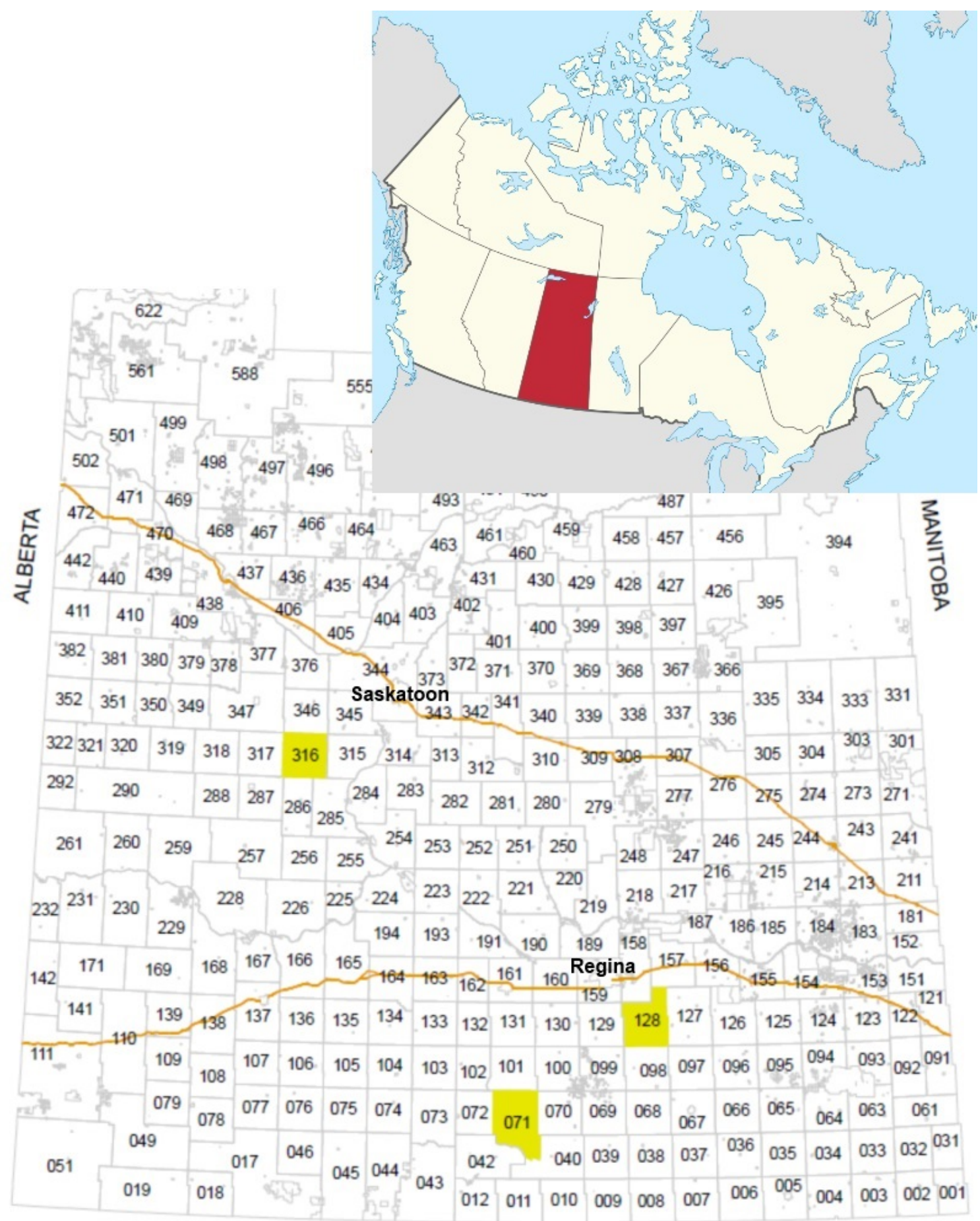

Figure 2. Map of three selected RMs (highlighted in yellow) in the province of Saskatchewan, and the location of the province within Canada. Credits: Map of Saskatchewan RMs prepared by Sarina Gersher using ArcGIS and source map data from Information Services Corporation (Including Sask Grid, Rural Municipalities Boundary Overlay, Sask Surface Cadastral, and Ownership Datasets). Source map data utilized and reproduced with the permission of Information Services Corporation. Additional GIS data from GeoBase; inset map of Canada from Wikipedia (Creative Commons licence). 
Further, to quantify changes in land ownership concentration we have introduced a metric we call the CLO4: the Concentration of Land Ownership by the four largest owners. ${ }^{10}$ We were inspired by the well-known industrial organization metric, CR4: the Concentration Ratio of the largest four firms (National Resources Committee, 1939; Rosenbluth, 1955). The CR4 measure reflects the cumulative share of the four largest firms in a given market. Similarly, the CLO4 quantifies concentration of ownership and control. CLO4 values are most revealing when compared across time, as we do in this article.

Each CLO4 is essentially a fraction, having a numerator (the area of land owned by the largest four entities in a given region) and a denominator (the total farmland area of the region). For the denominator, we used Statistics Canada's farm area for each RM (Statistics Canada, 2011a). For the numerator, we summed the land owned by the four largest private landowning entities (excluding lands owned by the Crown, the Saskatchewan Land Bank Commission, banks and credit unions, and community pastures). Though they did not occur near the top of lists of the largest landowners in the RMs under consideration, we have also excluded railways, school boards, wildlife preservation agencies, utility and resource companies, and First Nations lands. In doing so, we intend to capture private owners of farmland used for agricultural production. Also, in determining the largest landowners, we aggregated land that appeared under slightly different, but overlapping, title-holder names. This approach, referred to as the literal-legal methodology (used, for example, by Pritchard et al. 2012), involves combining titles when $50 \%$ or more of the names on titles are the same. For example, three titles with listed owners John Smith, John and Mary Smith, and Mary Smith would be considered one owner. ${ }^{11}$ We acknowledge that this approach can fail to combine entities that are, in fact, closely linked, e.g., where John and Mary Smith hold no land in joint names. Moreover, this methodology can combine entities that are, in fact, separate, e.g. divorced spouses who hold land in joint names. That said, because we are aggregating only among the largest entities in each RM, and because those are often corporations or similar entities, we believe that both miscombinations and missed combinations are limited and have little effect on CR4 values. We also aggregated individual owners with corporations owned by those individuals and we aggregated holdings by multiple corporations that had clear ownership linkages (for corporate inter-ownership examples see the Players section, below). Despite its limitations, this approach has the advantage of aggregating landholdings that are in all likelihood under the effective and legal control of particular individuals, families, or corporate entities.

\footnotetext{
${ }^{10}$ To quantify inequality in land distribution some analysts use Gini coefficients. We chose not to use this metric because it requires a determination of the total number of landowners, and thorough knowledge of how the many thousands of land titles should be aggregated.

${ }^{11}$ In adopting this approach, we in no way endorse the assumption that women's property ownership should be subsumed into the family unit simply by the act of marriage.
} 


\section{Limitations and potential error}

As noted, given the complexities of a one-million-plus-entry titleholder dataset, it is not possible to locate all investor entities, nor is it possible to determine all interconnections between entities. Also, while this article's analysis for 2014 relies predominantly on datasets and calculations, the analysis for 1994 was accomplished by having local residents examine their RM map for that year (or as close a year as possible). Thus, the methods for analyzing 1994 and 2014 data differ and may introduce some error. That said, we took such differences into consideration and believe that any resulting errors are small and would not alter the main findings of this article.

\section{Findings}

\section{Mapping changes in ownership patterns}

The three Saskatchewan RMs we studied showed large changes in land ownership patterns in the two decades between 1994 and 2014. Figures 3 to 5 depict one aspect of the shift: the area of land now owned by investment companies and similar entities. In all three RMs, there has been a sharp increase in the amount of land owned by investment funds, pension plans, other highly capitalized entities, and farmer/investor hybrids (Table 2), and there has been a sharp increase in concentration of ownership (Table 3).

Figure 3 (see page 28) highlights the land in RM 71 in 2014 owned by investors, investment companies, and similar entities. Those entities own more than 22,474 acres in the RM-over $8 \%$ of the farmland (Table 2). The authors considered including a comparative map for 1994, but that map would have been blank, that is, it would have shown no land owned by investment companies and similar entities. Nearly all of the 22,474 acres in the RM now owned by large, non-farmer investment interests have been bought up in just the past decade. The names and details of the pension funds, investment companies, and investors are given below, in the Players section.

Figure 4 highlights the land owned by pension funds, investment companies, investors, and similar entities in RM 128 in 2014-19,301 acres. Again, had we included a comparative 1994 map it would be largely blank. One caveat, however, is that land ownership in this RM in 1994 was more complex than in the other two. Several parcels appear to have been owned by people living outside Canada, some of whom rented their land to others. The largest holding of this type was 1,920 acres. We were not able to determine if this land should be classified as belonging to an investor. Also, that holding, though large, was much smaller than the 10,000 to $100,000+$ acre holdings of the investment companies we detail in the Players section. Thus, as Table 3 shows, there may have been some land in the RM in 1994 that could be classified as belonging to investors, though this is uncertain. That said, the area of such land would be small—not more than $1.5 \%$ of the farmland area. 
Figure 5 highlights land ownership in RM 316, Harris, in 2014. The situation in this RM is different than that in our other two study RMs. In RM 316, it is not investment companies or pension plans that are rapidly expanding their landholdings, instead, it is entities such as Nil-Ray Farms Ltd. and Cor Van Raay and his Van Raay Land Inc., which we classify as farmer/investor hybrids. These entities have bought 17,506 acres in RM 316, largely in the past decade. Moreover, Cor Van Raay and his company have bought almost 20,000 acres in the adjoining RM: Fertile Valley, number 285. A comparative 1994 map of land owned by investors, investment companies, and farmer/investor hybrids in the RM would show just 160 acres.

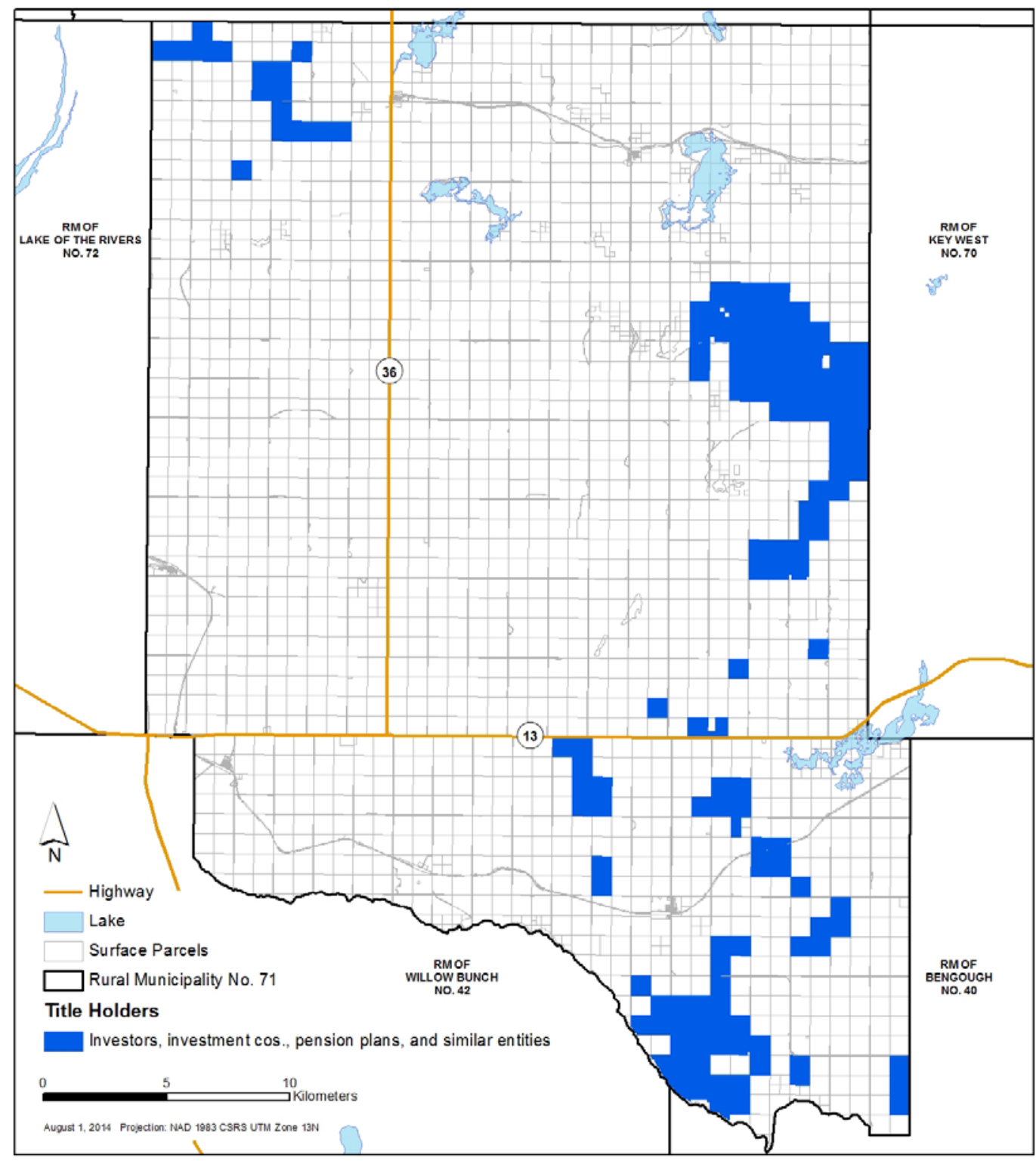

Figure 3. RM 71, Excel, in 2014 showing the area of land owned by investors (blue). Map prepared by Sarina Gersher using source map data from Information Services Corporation (Including Sask Grid, Rural Municipalities Boundary Overlay, Sask Surface Cadastral, and Ownership Datasets). Source map data utilized and reproduced with the permission of Information Services Corporation. Additional GIS data from Natural Resources Canada and GeoBase. 


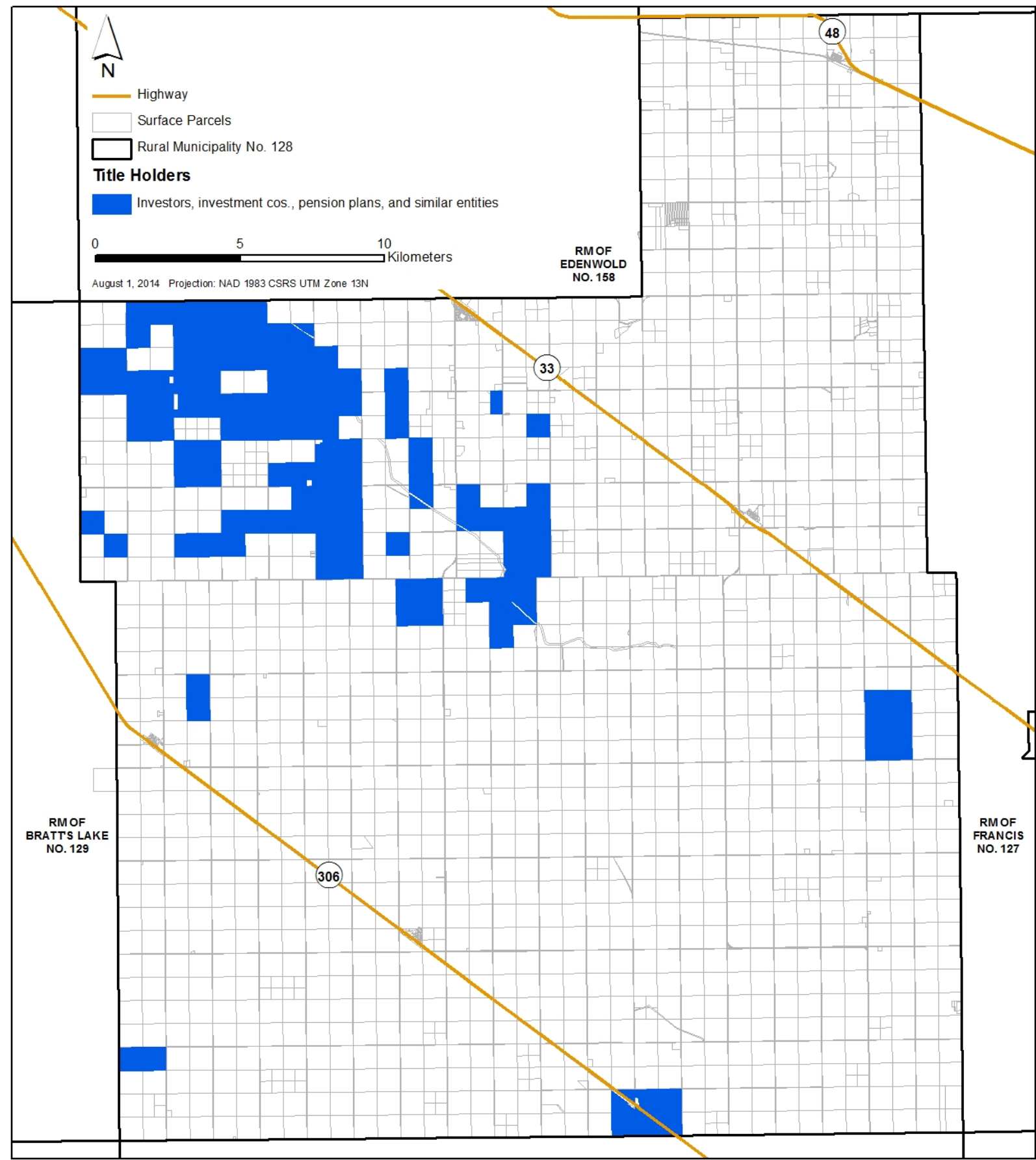

Figure 4. RM 128, Lajord, in 2014 showing the area of land owned by investors (blue). Map prepared by Sarina Gersher using source map data from Information Services Corporation (Including Sask Grid, Rural Municipalities Boundary Overlay, Sask Surface Cadastral, and Ownership Datasets). Source map data utilized and reproduced with the permission of Information Services Corporation. Additional GIS data from Natural Resources Canada and GeoBase. 


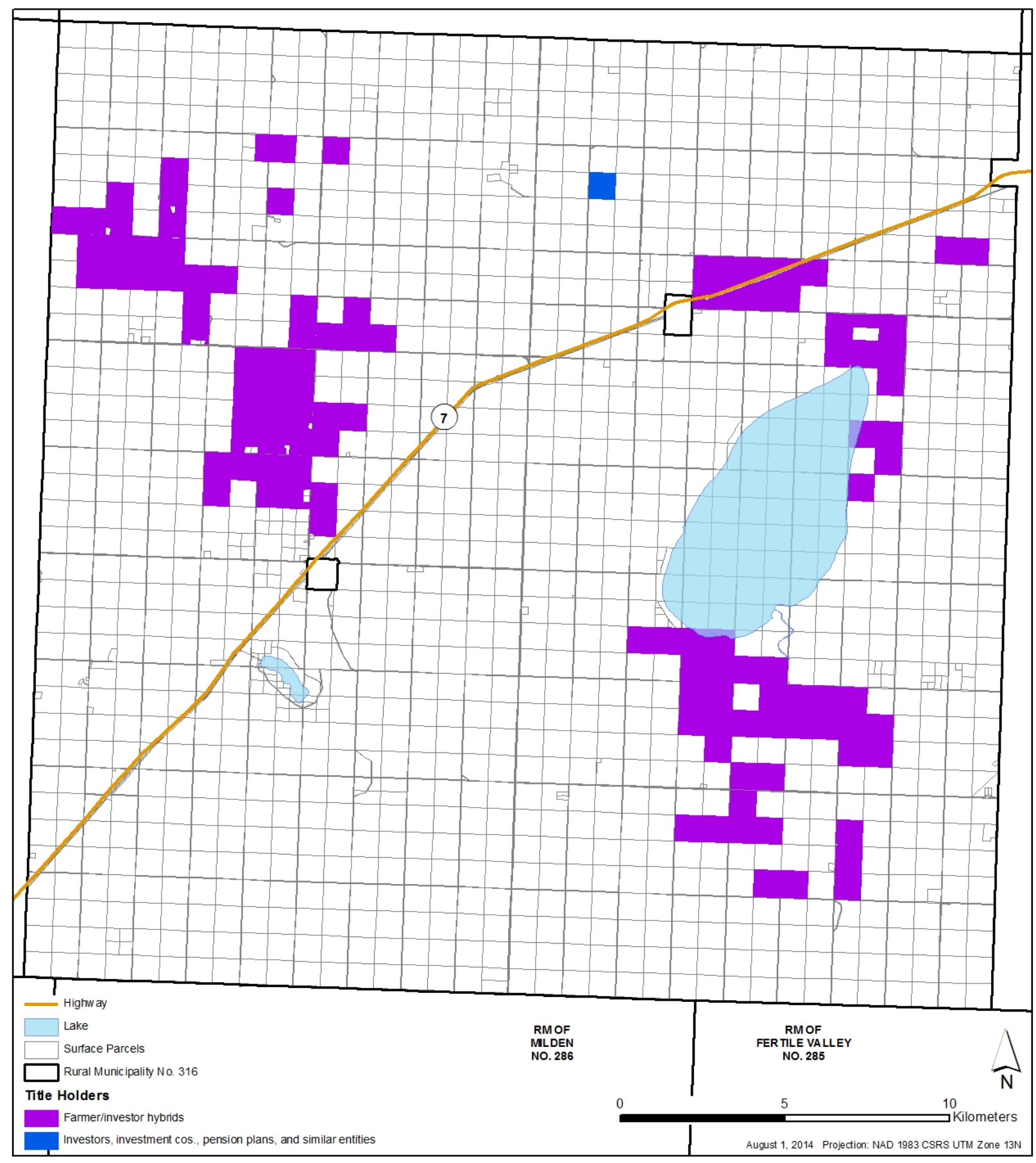

Figure 5. RM 316, Harris, in 2014 showing the area of land owned by investors (blue) and land owned by farmer/investor hybrids (purple). Map prepared by Sarina Gersher using source map data from Information Services Corporation (Including Sask Grid, Rural Municipalities Boundary Overlay, Sask Surface Cadastral, and Ownership Datasets). Source map data utilized and reproduced with the permission of Information Services Corporation. Additional GIS data from Natural Resources Canada and GeoBase. 


\begin{tabular}{|c|c|c|c|c|c|c|}
\hline & \multicolumn{2}{|c|}{$\begin{array}{l}\text { Area of farmland owned by } \\
\text { investment funds, pension } \\
\text { plans, and other investors } \\
\text { (acres) }\end{array}$} & \multicolumn{2}{|c|}{$\begin{array}{l}\text { Area of farmland owned by } \\
\text { farmer/ investor hybrids } \\
\text { (acres) }\end{array}$} & \multicolumn{2}{|c|}{$\begin{array}{l}\text { Portion owned by } \\
\text { investment funds, etc. } \\
\text { and hybrids (percent) }\end{array}$} \\
\hline & 1994 & 2014 & 1994 & 2014 & 1994 & 2014 \\
\hline RM 71, Excel & $\sim 0$ & 22,474 & 0 & 0 & $<<1 \%$ & $8.5 \%$ \\
\hline RM 128, Lajord & $0-3,200$ & 19,301 & 0 & 0 & $<1.5 \%$ & $9.4 \%$ \\
\hline RM 316, Harris & 160 & 160 & 0 & 17,506 & $<<1 \%$ & $13.1 \%$ \\
\hline Average for $3 \mathrm{RMs}$ & & & & & & $10.3 \%$ \\
\hline
\end{tabular}

Table 2. Area and portion of land owned by investment funds, pension plans, and other investors or by farmer/investor hybrids, RMs 71, 128, and 316, 1994 and 2014. Data sources: 2014 source map data adapted from Information Services Corporation Ownership Dataset. Source map data reproduced with the permission of Information Services Corporation. 1994 data taken from archived maps of individual RMs.

Table 2 quantifies the significant penetration of investment companies, investors, pension plans, and farmer/investor hybrids into the three study RMs. In little more than a decade, these companies and individuals have purchased $10.3 \%$ of the farmland in these RMs. ${ }^{12}$

\section{The players: Who is buying Saskatchewan's farmland?}

Our study of land titles data reveals many interesting entities buying farmland. Most are new entrants - initiating their purchases within the past decade. Despite this, some already own huge areas of farmland-in some cases more than 100,000 acres province-wide. The classes of entities buying large areas of farmland include public pension plans, investors and investment companies, farmer/investor hybrids, and large-scale farmers.

\section{Public pension plans}

Canada Pension Plan. The Canada Pension Plan Investment Board (CPPIB) owns 545 acres in the three study RMs-113,867 acres in the province as a whole. The owner listed on the land titles is 101138678 Saskatchewan Ltd., which is owned by Assiniboia Farmland Holdings Limited Partnership, the General Partner of which is CPPIB Assiniboia Inc. The CPPIB acquired the land in late 2013 from one of Saskatchewan's largest farmland investment companies: Assiniboia Farmland Limited Partnership (CPPIB, 2013). The CPPIB is an arms-length crown corporation that manages approximately $\$ 200$ billion in public pension assets. It plans to buy as much as \$3 billion worth of additional farmland in Canada, the United States, Australia, New Zealand, and Brazil by the end of the decade (Atkins, 2013).

\footnotetext{
${ }^{12}$ Of course, an interesting question here is what share of the land in the area has been placed on the market, and thus what percentage of this share is being purchased by investment companies, investors, pension plans and farmer/investor hybrids. We would like to thank an anonymous reviewer for this important question that we will pursue in the province-wide study on land grabbing and land concentration that we are currently conducting.
} 
Investors and investment funds, companies, and partnerships

Agcapita Farmland Investment Partnership. Alberta-based Agcapita GP II Ltd. is the listed owner of 952 acres in the three study RMs. Overall, Agcapita and its investors own a total of 29,661 acres in the province through a number of investment funds (Agcapita GP II Ltd., GP III Ltd., and GP IV Ltd.).

Agco Ag Ventures Limited Partnership. The General Partner in Agco Ag Venture LP is 101168777 Saskatchewan Ltd. That company is the listed titleholder on 318 acres in the three RMs under study, and 15,453 acres in the province. SaskWorks labour-sponsored venture capital fund has a \$20 million investment in Agco, which SaskWorks describes as "focused on the acquisition and lease-out of farmland in Saskatchewan" (SaskWorks, 2011) and "a low-risk form of participation in the growing market of agricultural investment” (SaskWorks, 2014).

AGMW Regina Farms Ltd. AGMW is the listed owner of 9,249 acres in the three RMs and 21,205 acres in the province as a whole. Shareholders of AGMW include Vancouver's Aquilini family (via 638769 B.C. Ltd.), who also own the Vancouver Canucks hockey team; Lululemon founder and part owner Dennis (Chip) Wilson (via 0823038 B.C. Ltd.); and Frank Giustra, President of Fiore Capital Corporation.

Andjelic, Robert, and Andjelic Land Inc. Mr. Andjelic and his corporation are the listed owners of 17,429 acres in the three study RMs, and more than 161,000 acres in the province. Mr. Andjelic, who lives in Alberta, appears to be the largest private owner of farmland in Saskatchewan. He owns land in 79 RMs and, according to interviews with local farmers, he rents his land to local farmers. His holdings may be worth $\$ 100$ to $\$ 200$ million dollars. ${ }^{13}$

Blueberry \& Papaya Farms Ltd. Blueberry \& Papaya Farms and affiliated companies-Topsoil Farm Land Management (II) Inc., Kiwi \& Mango Farms Ltd., Black Dirt Farm Land Management Inc., PFM Holdings Inc., PFM Capital Inc., and others-are among the largest landowners in the province with 84,311 acres overall, and 319 in the study RMs. Investors in Topsoil Farm Land Management (II) Inc. own approximately 23,440 acres, according to land titles data. Werklund Capital Corporation, based in Calgary, says that it is "the larger owner of Topsoil partnership units" and that "The TopSoil Farm Land Management Fund focuses on the acquisition and lease-out of top quality Saskatchewan farmland to first tier producers" (Werklund, 2014). Figure 6 (see page 33) gives a sense of the complexity of the ownership structures and financial connections of these investment vehicles, especially in contrast with the simpler structures of owner-operator family farms.

\footnotetext{
${ }^{13}$ This range is an approximation intended to give some sense of the value of 161,000 acres of farmland. The range is based on a land price range from approximately $\$ 600$ to $\$ 1,200$ per acre.
} 


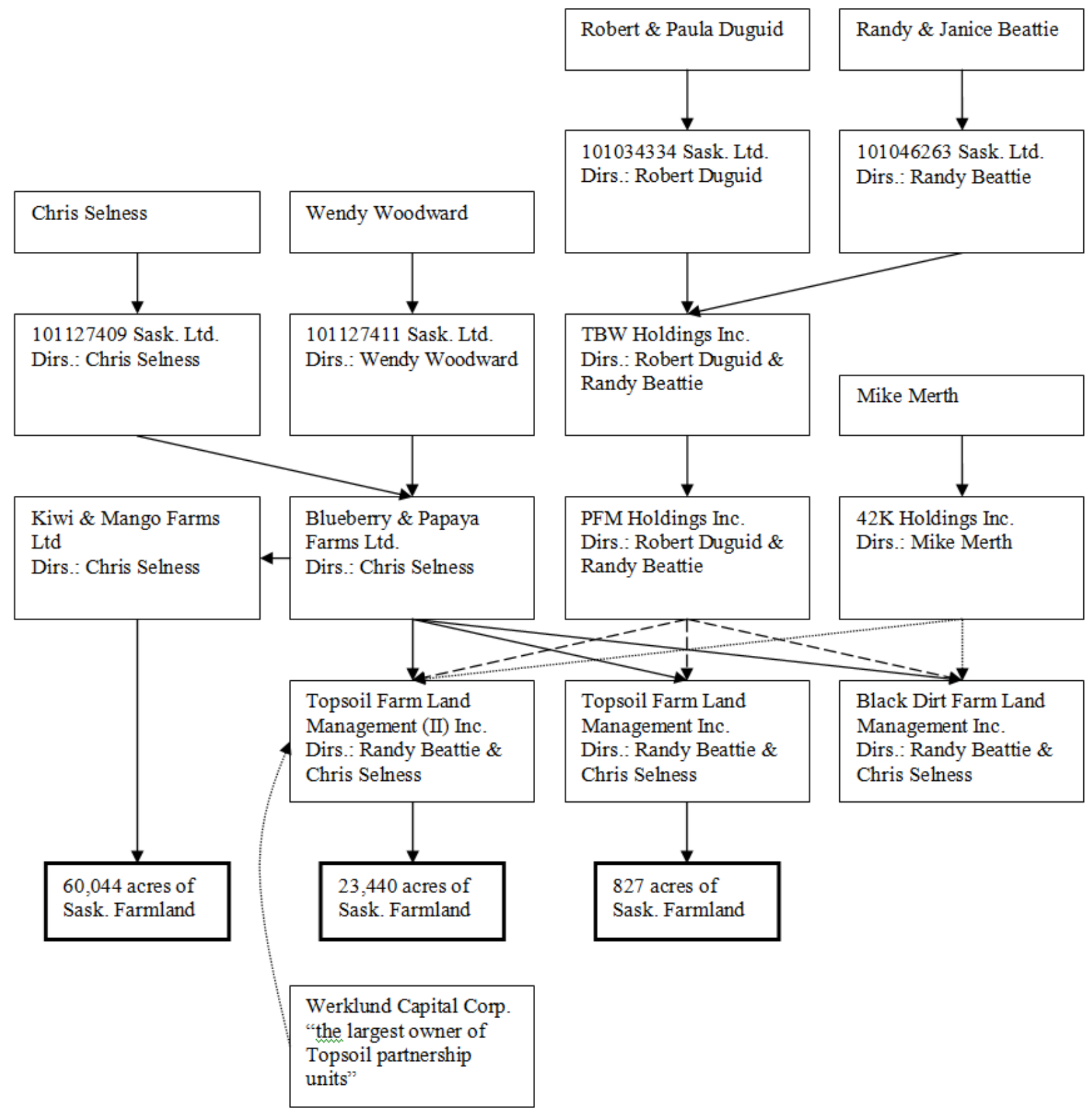

Figure 6. A simplified view of the ownership structure and financial linkages of Blueberry \& Papaya Farms Ltd. and affiliated companies. Sources: ISC online Corporate Registry. Note: the actual ownership, investment, and management structure is more complex than shown here, and may differ in details. This graphic is only illustrative of certain connections. 
HCI Ventures Inc. HCI is a "land investment company that offers land rental opportunities to Western Canadian farmers” (HCI Venture Ltd., 2014). HCI owns 8,869 in the three study RMs and 113,718 in the province. HCI is owned by the Hokanson family of Alberta (O'Brien \& Kirbyson, 2012).

Netherlands Investment Company of Canada Limited. Netherlands Investment Company owns 160 acres in the three study RMs and 12,446 acres in the province. The owner is the United Transatlantic Mortgage Companies, The Hague, Netherlands.

UL Farmlands Ltd. This company has seven shareholders, including four investment or holding companies based in Vancouver. UL Farmlands Ltd. owns 2,071 acres in our target RMs and 9,158 acres in the province as a whole.

Yang's Crop Inc. Yang's Crop Inc. owns 2,001 acres in our three target RMs and 10,031 in the province. Its owner is the British Colombia-based Yang's Magic Crop Limited Partnership.

\section{Farmer/investor hybrids}

In studying maps and land titles data we found two entities, Nil-Ray Farms Ltd., and Cor Van Raay and Van Raay Land Inc., that have, in the past decade, bought up tens of thousands of acres of land. These are large, rapidly growing entities that have only recently bought land in the RMs in question, and, as such, they differ from long-established, usually smaller and slower expanding family farms. But Nil-Ray Farms and Cor Van Raay and his company also differ from investment companies in that the former appear to be taking a role in managing the farming operations on their lands (though it is likely that they are also interested in the long-term returns on their sizable land investments). To distinguish these entities from family farms on the one hand, and investment companies on the other, we therefore label them farmer/investor hybrids.

Cor Van Raay and Van Raay Land Inc. Cor Van Raay and his company are the listed owners of 8,596 acres in our three study RMs and 33,730 acres in the province. He acquired much of this land in the past ten years and he manages the farming of the land he purchases.

Nil-Ray Farms Ltd. Nil-Ray is owned by the Nilsson brothers, Brian and Lee (via 400369 Alberta Ltd.) Until recently, the Nilsson brothers owned one of Canada's two largest beef-packing plants. They continue to own cattle auction markets and other assets through a complex corporate structure. Nil-Ray Farms owns 8,923 acres in our study RMs and 14,802 in the province. 


\section{Concentration measures}

As noted in the methodology section, to quantify changes in land ownership concentration we use the CLO4, the Concentration of Land Ownership among the four largest private owners. Table 3 shows CLO4 values for the three RMs for 1994 and 2014. In each RM, the portion of land owned by the largest four owners has more than doubled, or nearly tripled. On average, in these RMs, the largest four entities own $21 \%$ of all the farmland-more than a fifth. This is up from just $8.6 \%$ two decades ago. One driver for these rapid increases in concentration is recent purchases by farmland investment funds, investors, pension plans, and farmer/investor hybrids. Four such entities, with holdings ranging from 84,000 to 161,000 acres each, make up the four largest private landowners in the province. But another driver, perhaps equally or more significant, is the expansion of established, locally based family farms. In all three study RMs, one or two of the four largest landowners appear to be family farms. And if we include collectively owned Hutterian Brethren farms in that definition, then in each RM two or three of the four largest landowners are farms, not investors, investment companies, or farmer/investor hybrids. Our study thus reveals a dual phenomenon: rapid farmland acquisition by investment companies and similar entities and, simultaneously, expansion of some existing farms and attendant increases in land ownership concentration.

\begin{tabular}{lll}
\hline & \multicolumn{2}{c}{ CLO4 } \\
\hline RM 71, Excel & 1994 & 2014 \\
\hline RM 128, Lajord & $7.3 \%$ & $15.7 \%$ \\
\hline RM 316, Harris & $6.8 \%$ & $19.1 \%$ \\
\hline Average of the 3 RMs & $11.8 \%$ & $28.1 \%$ \\
\hline
\end{tabular}

Table 3. Farmland ownership concentration: CLO4 values for three RMs, 1994 and 2014. Data sources: 2014 source map data adapted from Information Services Corporation Ownership Dataset. Source map data reproduced with the permission of Information Services Corporation. 1994 data taken from archived maps of individual RMs.

\section{Larger farms increase land concentration}

Land ownership concentration (the land owned by farmers or others) and increasing farm size (a function of land ownership and land rental) are linked but distinct phenomena. Because of the importance of rented land in many farm operations, land ownership concentration and farm size measures can move in opposite directions-e.g., farms can get larger but land ownership can become less concentrated-though we would usually expect the two measures to move in tandem. Keeping this distinction between ownership concentration and farm size in mind, it is instructive to examine how the two are related. In addition to land ownership concentration driven by investor purchases, to what extent do purchases by farmers and the expansion of 
existing farms contribute to concentration? To answer this question we examined Statistics Canada data and found significant gaps in what these numbers reveal.

There is a long history of increasing farm size in Saskatchewan going back at least to the 1920s (Figure 7). Total land per farm (owned and rented) has increased steadily for many decades. The total area of the average Saskatchewan farm increased from 1,152 acres in 1996 to 1,668 in 2011 (Statistics Canada, Census of Agriculture) —a 45\% increase in 15 years. Leaving aside rented land for the moment, we see that land owned per farmer grew slowly in the 1980s and early 1990s, but began to increase more rapidly beginning in 1996. From 1996 to 2011, the average area of land owned per farm increased from 697 to 1072 acres, a 54\% increase in 15 years. Given the high farmland prices noted above, such rapid expansion is increasingly challenging and costly for farms and requires them to devote more and more resources to farmland acquisition, possibly eroding their long-term viability, economic resilience, and capacity to adapt to challenges and changes. The downside of rapid farm expansion is seen in the $60 \%$ increase in farm debt in Saskatchewan in the past decade.

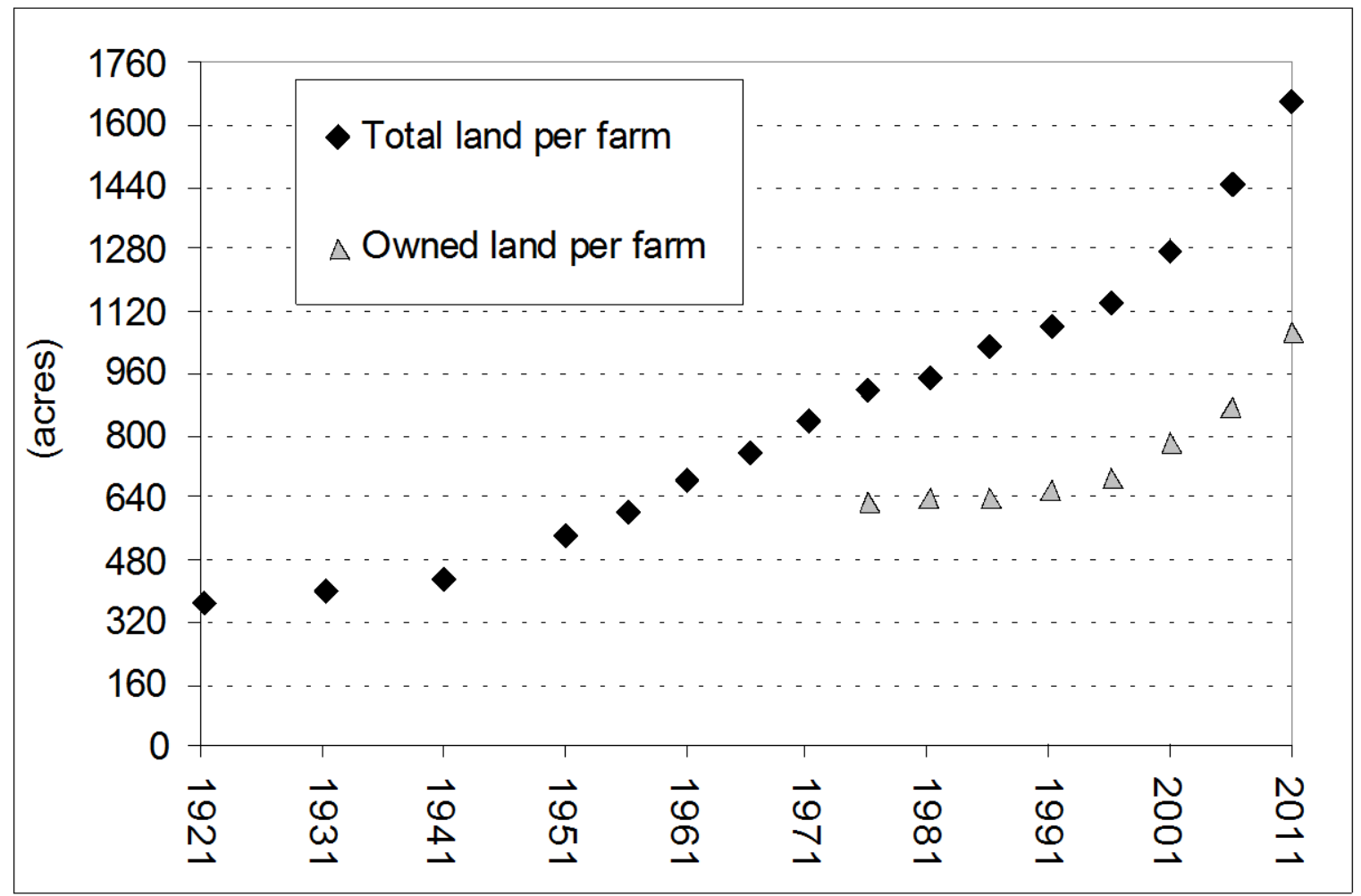

Figure 7: Saskatchewan average farm size (rented and owned land), and average land owned, 1921 to 2011. Sources: Statistics Canada, Selected Historical Data from the Census of Agriculture, Cat. No. 95632-XWE; and Statistics Canada, Census of Agriculture, various years.

These changes occurred over the 1996-2011 period, when the number of farms in the province fell from 56,995 to 36,952. In short, there are fewer farmers and each owns more land, as farms 
of all sizes continue to get bigger. While additional statistical analysis could shine additional light on the situation, it seems virtually certain that farm expansion is leading to concentration of land ownership among farmers.

Further, Statistics Canada averages may understate farm size and growth rate. According to Statistics Canada, in 2012, the average Saskatchewan farm had revenues of \$301,965, an area of 1,668 acres, and therefore revenues averaging \$181 per acre (keeping in mind that averages can sometimes paint a distorted picture). Another source, however, tax filer data, shows that farms with revenues over $\$ 500,000$ - just $16 \%$ of Saskatchewan farms-produced $64 \%$ of revenues in 2012 (Statistics Canada CANSIM 002-0046). These 6,055 large farms accounted for nearly two thirds of Saskatchewan's production and had average revenues of \$1.25 million each. If the per-acre revenues of these farms were close to the provincial average of \$181 per acre (a good assumption because these farms make up 64\% of total revenues and thus dominate the averages), then a farm with $\$ 1.25$ million in revenues would have a land area of roughly 6,900 acres. Because they produce two thirds of Saskatchewan revenues, these large farms may be more representative of actual farm size than the 1,668 acre farms that Statistics Canada averages imply.

Not only do representative Saskatchewan farms appear to be much larger than averages indicate, the rate of growth may be faster as well. The number of farms with revenues greater than \$500,000 tripled between 2005 and 2012, and their share of total revenues nearly doubled from 33\% to 64\% (Statistics Canada CANSIM 002-0046). While inflation and commodity price changes were a factor in these increases (the $\$ 500,000$ line has been held constant while inflation eroded the purchasing power of the dollar and some commodity prices increased), given the magnitude of the changes, inflation and commodity price changes can probably explain only a small part of the change. The bulk of the change appears to be a result of Saskatchewan farms rapidly growing in size. This growth is almost certainly contributing to increasing land ownership concentration.

\section{Impact on community cohesion and vitality}

Having analyzed and quantified large and rapid changes in concentration, investor ownership, and other land ownership patterns in the three RMs, we now turn to our analysis of the qualitative data collected for this study. This section draws upon existing literature, participant observation, and interviews with residents living in the three municipalities, to explore the subtle but experienced social impact of changing patterns of land ownership in the three municipalities. Most significantly, we focus on the ways in which larger farms are affecting rural life and community cohesion.

Many of the changes and losses that prairie rural communities are currently experiencing have historical roots. The trend towards larger farming units with more concentrated land ownership has meant a continuous decline in the number of farming families. From the peak of farming populations in the 1930s to the present, communities that are primarily reliant on 
agriculture have been declining unevenly but steadily over many decades (Carlyle, 1994). As one farmer we interviewed stated, "There is an ongoing emptying of the countryside. Rural communities have been under duress ever since settlement, and what is going on is really part of a long process of de-settlement."

Larger farms and fewer farm families mean that many rural communities are unable to sustain the services and institutions that require a critical mass of users to continue to operate. The steady erosion of schools, hospitals, churches, and post offices, as well as the closing of businesses, banks, and grain elevators creates a downward spiral, making it more difficult to continue to live in these communities. Although this can be partially offset, in some instances, with improved infrastructure and communications systems, the physical decline in many prairie rural communities is visible on town and village main streets. The depopulation of farming communities is even more apparent in the many abandoned farmyards along rural roads. The remnants of working farmyards, where they haven't been entirely erased, are being replaced by more centralized grain and machinery storage yards without human habitations on site.

In the case of local farm families acquiring larger tracts of land, the effects of the consolidation tend to be less visible and dramatic than outside takeovers. However, the shared histories, family, and community ties conspire to mask the underlying changes. As noted above, the patterns of increasing farm size are familiar to rural citizens. Most if not all of the families that are currently farming have themselves undertaken some expansion within their farming lives. So it may be more difficult to see where local consolidation of land holdings and farm expansion become not only a "difference in scale," and usually a difference in speed, but a “difference in kind.” When local family farms expand, they displace and remove other farmers from their own and adjacent communities, but they themselves usually remain in their home communities. As they are known to their neighbours and may well continue to participate in their local community life, the expansion of their land holdings may be less likely to signal an unacceptable shift to those around them. As one farmer told us "If the local guy becomes the big farmer, he still has some contact with the community, he still resides somewhere, he still is somewhere near a school, a church, a store, no matter how big he is. If it is corporate, is it Hong Kong money? How is this being done? You see that it is completely out of your control.” The differential impact of family farms expanding and consolidating their land base versus new, “outsider” investors buying comparable amounts of land requires further research. For example, among others, a key issue is who ends up working the land that investors buy. If a farm manager with few or no ties to the community is hired, then the effect might differ considerably than if the land is rented to a local farming family.

Given the long-term and ongoing decline in the number of farm families, it is difficult to gauge the specific effects of the recent rapid spate of land purchases by investors, pension funds and outside operators compared to generalized increased concentration of land by local farmers. But interviews and observations in the three municipalities revealed some questions that are 
worth noting. While larger farming units, including the Hutterite colonies, ${ }^{14}$ are more likely to take advantage of economies of scale available from dealing with larger corporate entities (e.g., for farm inputs, machinery, or farm-related services) rather than patronizing smaller, local businesses, is this business strategy even more pronounced with outside investors? For example, local Municipal Hail contracts have declined in the Harris Municipality, \#316, as broadly based land owners spread their risk of losing crops to hail by owning land in disparate parts of the province instead of buying local hail insurance. Therefore, with outside owner/operators, is familiarity with, and loyalty to, local businesses largely absent-making them superfluous?

Furthermore, outside investors lack the connection to the local context that is built over years (and generations) in farming communities. This lack of connection can take the form of expressed lack of trust. For example, when Nil-Ray Farms purchased large tracks of pasture land in the Harris Municipality, they not only upgraded the fences but also put locks on the gates. Locking pasture gates is a highly unusual measure in this community and demonstrates a lack of awareness and/or mistrust of the ethos and traditions of the local communities where they are purchasing land.

Community cohesion is further disrupted when informal information networks are no longer possible. Distant and large-scale buyers are not on "coffee row" to discuss their plans or intentions. The speed, scale, and lack of transparency surrounding the current spate of land acquisitions appears to be creating unease and added concern about the prospects for young and beginning small- to medium-scale farmers. As one farmer put it, "The main feeling here is that the young farmers feel threatened... Investment companies and large farmers are buying up the land. The price of land is so much higher. You don't know how much to offer. You don't know that it's gone until it is sold."

The loss of community cohesion and lack of connections with those who farm nearby land was expressed in many ways. As one farmer lamented, "The neighbourly thing is not here anymore. People don't talk to each other. Now you don’t see anyone anymore.” Instead of sharing a feeling of solidarity with other farmers working hard to get the crop in during harvest, she noted that "now you don't see anyone at all until a fleet of combines rolls in and takes off the crop and is gone.” This loss of community, linked not only to the entry of new players and outside operators but also to a generalized increased concentration of land ownership, was repeatedly mentioned in the interviews. Losing the physical and social presence of erstwhile neighbours entails losing their knowledge, diverse skills, and aid when needed, all of which undermines the cultural diversity and wisdom of place necessary for the resilience and sustainability of rural environments (Wiebe, 2012).

\footnotetext{
${ }^{14}$ Hutterites, an ethno-religious group characterized by pacifism and communal farming, migrated to western Canada in the early 20th Century to establish village settlements (colonies) on collectively held land.
} 


\section{Conclusion}

Our research examined changing land ownership patterns in rural Saskatchewan. To test a new methodology using land title data and GIS software, we centered our research on three rural municipalities. The research, combined with Statistics Canada data and interviews with local residents, demonstrates some interesting developments and points to a series of questions for further research. Our analysis reveals an ongoing concentration of land ownership driven, in part, by a newer phenomenon of land grabbing by outside investors and farmer/investor hybrids, but also as a result of the ongoing expansion of land ownership by local farmers. The social impact of these changing land ownership patterns is an ongoing but perhaps more acute weakening of community cohesion and vitality.

In many ways, our research raises more questions than answers. We initially thought that this would be a fairly straightforward quantitative process of measuring change using GIS software supplemented by some interviews with residents in the three rural municipalities. Instead, at every turn, we found complex realities characterized by new social and economic arrangements that have yet to be analyzed. For example, as more farmland is being rented out and land ownership is also increasingly concentrated, more hired farm labour is needed. While our research sheds light on the changes in land ownership, the new players involved, and ongoing concentration of land by farmers themselves, little is known about the nature and structure of these new labour relations and farm labourers' links to rural communities. While some of that labour is being provided by the farmers who sold their land, we were also told that farm work is now being done by "transients," "drifters and drunks," and "Mexican Mennonites." ${ }^{15}$ More research is needed to shed light on the following: How will the changes in land ownership structures affect the kinds of agriculture work available? How will work relationships, status, and remuneration for food producers and farm labourers be reordered?

As the average age of prairie farm populations continues to rise, the influx of outside capital with the attendant rise in land values represents an even higher barrier for would-be young new entrants into farming. What effects will the investor ownership pattern of land have on young entrants into farming? Will would-be young farmers cede the prospect of owning land and opt to become renters only? While the management arrangements of large family farms may not differ significantly from smaller units, what kinds of land and production management structures are investors instituting?

\footnotetext{
15 Thanks to Jim Handy (a historian at the University of Saskatchewan) for pointing out that in a much earlier time, it was this very type of labourer- "drifters and drunks"- that The Economist and others argued would no longer need to be employed with enclosure and the consolidation of land into capitalist agriculture. In 1851, The Economist argued that the only people thrown out of work by enclosures were men of "dissolute and unsteady habits...very commonly consum[ing] with utter improvidence the large wages they earned during the summer months, and [gone] into the union workhouse during the winter." The newspaper also mentioned they drank too much and were "halflabourer, half vagabond" (Economist, 1851). This is interesting because back then the consolidation of land was meant to force these people from the rural areas (to the cities where their labour could be more easily disciplined), while in today's context a similar process (consolidation of land and having it farmed by tenants) is attracting "drifters and drunks" to the countryside.
} 
The research also points to a number of key questions related to social and environmental sustainability: How do these structural changes in land ownership affect the owners/operators relationship to, and use of, the land? What effects does this have on production sustainability and ecological health? How does the identity of the landowner matter in this process of concentration? That is, how are the environment and community more greatly and negatively affected by the activities of land grabbers than by land concentration by local farmers?

This article examined changes in land ownership patterns in just three rural municipalities in Saskatchewan and revealed that the changing structure of land ownership poses a range of important questions that demand further research. There is an urgent need to document and analyze the scope of the changes currently underway in Saskatchewan and the rest of Canada.

\section{Acknowledgements}

This research was made possible with funding from the Canada Research Chairs program, the Social Sciences and Humanities Council of Canada, and the University of Manitoba. We gratefully acknowledge the assistance provided by Sarina Gersher who provided much needed GIS expertise and developed the maps. We are especially grateful of the support provided by Dr. Geoff Cunfer and his Historical GIS Lab at the University of Saskatchewan. All maps were prepared using GIS data provided by Information Services Corporation of Saskatchewan. And we are grateful to the University of Manitoba's legal department for their work in drafting a legal agreement with Information Services Corporation of Saskatchewan for use of their titleholder dataset. We also wish to acknowledge the assistance of the National Farmers Union. Without the cooperation of farm families and their democratic organizations, research such as ours would be much more difficult. Finally, we would like to thank two anonymous reviewers for their insightful comments.

\section{References}

AAFC. (2014). Agriculture and Agri-Food Canada. Canada's farm income forecast for 2013 and 2014. Ottawa: Minister of Agriculture and Agri-Food. Retrieved from http://www.gov.pe.ca/photos/original/af_stat_CFI2014.pdf

Agcapita Farmland Investment Partnership (2009, April 20). Want to invest in farmland using your TFSA - Agcapita makes it possible [Press release]. Retrieved from http://www.usetdas.com/TDAS/newsArticle.aspx?NewsID=13476

Athins, E. (2013, December 12). CPPIB buys Saskatchewan farms in \$128-million deal. The Globe and Mail. Retrieved from http://www.theglobeandmail.com/report-onbusiness/cppib-buys-saskatchewan-farms-in-128-million-deal/article15910970/ 
Burch, D., \& Lawrence, G. (2009). Toward a third food regime: Behind the transformation. Agriculture and Human Values, 26, 267-279.

Canada Pension Plan Investment Board (CPPIB). (2013, December 12). Canada Pension Plan Investment Board to acquire Saskatchewan farmland portfolio [Press release]. Retrieved from http://www.cppib.com/en/public-media/news-releases/2013/CPPIB-Saskatchewanfarmland-Dec-2013.html

Carlyle, W. J. (1994). Rural population change on the Canadian prairies. Great Plains Research: A Journal of Natural and Social Sciences, Paper 156. Retrieved from http://digitalcommons.unl.edu/greatplainsresearch/156

Clapp, J. (2014). Financialization, distance and global food politics. Journal of Peasant Studies, 41(5), 797-814. doi: 10.1080/03066150.2013.875536

Cotula, L. (2012). The international political economy of the global land rush: A Critical appraisal of trends, scale, geography and drivers. Journal of Peasant Studies, 39(3-4), 649-680.

De Schutter, O. (2010, November). The green rush: The race for farmland and the rights of land users. A working paper published by the Catholic University of Louvain, Belgium.

De Schutter, O. (2011). How not to think about land grabbing: Three critiques of large-scale investments in farmland. Journal of Peasant Studies, 38(2), 249-279.

Development and Change. (2013). Governing the global land grab: The role of the state in the rush for land [Special issue]. 44(2).

Economist. (1851, September 6). Cheap food and rural wages.

Fairbairn, M. (2014). "Like gold with yield”: Evolving intersections between farmland and finance. Journal of Peasant Studies, 41(5), 777-795.

Farm Credit Canada (FCC). (2013). Historic farmland values: 1985-2013. Retrieved from https://www.fcc-fac.ca/fcc/about-fcc/corporate-profile/reports/farmland-values/farmlandvalues-historic.pdf

Ferguson, S., Furtan, H., \& Carlberg, J. (2006). The political economy of farmland ownership regulations and land prices. Agricultural Economics, 35, 59-65.

Franco, J., \& Borras, S. M. Jr. (Eds.). (2013). Land concentration, land grabbing and peoples’ struggles in Europe. Published by Transnational Institute for the European Coordination of Via Campesina and Hands off the land network. Retrieved from http://www.tni.org/sites/www.tni.org/files/download/land_in_europe-jun2013.pdf 
Globalizations. (2013). Land grabbing and global governance [Special issue]. 10(1).

Government of Saskatchewan. (2002, December 19). New farm ownership rules effective January $1^{\text {st }}$ [Press release]. Retrieved from http://www.gov.sk.ca/news?newsId=133e5149-53cd-4ddc-abe1-58d038ca4825

GRAIN. (2008). Seized: The 2008 grab for food and financial security. Retrieved from http://www.grain.org/article/entries/93-seized-the-2008-landgrab-for-food-and-financialsecurity

GRAIN. (2012). Responsible farmland investing? Current efforts to regulate land grabs will make things worse. Retrieved from http://www.grain.org/article/entries/4564-responsiblefarmland-investing-current-efforts-to-regulate-land-grabs-will-make-things-worse

GRAIN. (2014). Hungry for land: Small farmers feed the world with less than a quarter of all farmland. Retrieved from http://www.grain.org/article/entries/4929

Gunnoe, A. (2014). The political economy of institutional landownership: Neorentier society and the financialization of land. Rural Sociology, 79(4), 478-504.

HCI Venture Ltd. (2014). HCI Ventures. Retrieved from http://www.hciventures.ca/

Hursh, K. (2010, March 23). Saskatchewan farmland prices remain strong. Saskatoon StarPhoenix. Retrieved from http://www2.canada.com/saskatoonstarphoenix/news/business/story.html?id=406c8c2448f5-4f2c-b419-810b8a973483

Isakson, S. R. (2014). Food and finance: The financial transformation of agro-food supply chains. Journal of Peasant Studies, 41(5), 749-775.

Journal of Peasant Studies. (2011). Forum on global land grabbing. 38(2).

Journal of Peasant Studies. (2012). The new enclosures: Critical perspective on corporate deals [Special issue]. 39(3-4).

Knutilla, M. (2003). Globalization, economic development and Canadian agricultural policy. In H. Diaz, J. Jaffe \& R. Stirling (Eds.), Farm Communities at the Crossroads: Challenge and Resistance (pp. 289-302). Regina, CA: Canadian Plains Research Centre.

La Vía Campesina. (2013). Land is life: La Vía Campesina and the struggle for land. Notebook \#5. Retrieved from http://viacampesina.org/downloads/pdf/en/EN-notebook5.pdf 
L’Italien, F. (2012, March). L'accaparement des terres et les dispositifs d'intervention sur le foncier agricole : Les enjeux pour l’agriculture québécoise. Institut de recherche en économie contemporaine. Retrieved from http ://www.upa.qc.ca/ScriptorBD/publication/204694/Accaparement\%20des\%20terres\% 20Mars\%202012.pdf

Magnan, A. (2012). New avenues of farm corporatization in the prairie grain sector: Farm family entrepreneurs and the case of One Earth Farms. Agriculture and Human Values, 29(2), 161-175.

Magnan, A. (2014). The rise and fall of a prairie giant: The Canadian Wheat Board in food regime history. In S. Wolf \& A. Bonanno (Eds.), The Neoliberal Regime in the Agri-Food Sector: Crisis, Resilience and Restructuring (pp. 73-90). New York: Routledge.

Margulis, M. E., McKeon, N., \& Borras Jr., S. M. (2013). Land grabbing and global governance: Critical perspectives. Globalizations, 10(1), 1-23.

McMichael, P. (2012). The land grab and corporate food regime restructuring. Journal of Peasant Studies, 39(3-4), 681-701.

Murmis, M., \& Murmis, M. R. (2012). Land concentration and foreign and ownership in Argentina in the context of global land grabbing. Canadian Journal of Development Studies, 33(4), 490-508.

National Resources Committee. (1939). The Structure of the American Economy, Part 1. Basic Characteristics. Washington: Government Printing Office, Appendix 8.-Summary of Concentration Data, Classification, and Price Data for Manufacturing Industries.

NFU. (2010). National Farmers Union. Losing our grip: How a corporate farmland buy-up, rising farm debt, and agribusiness financing of inputs threaten family farms and food sovereignty. Saskatoon, Saskatchewan: National Farmers Union. Retrieved from http://www.nfu.ca/sites/www.nfu.ca/files/06-07-losing_grip.pdf

O’Brien, F., \& Kirbyson, G. (2012, April). Land values: From farms to industrial sites, raw land is proving a hot investment across the Western prairies. Western Investor. Retrieved from http://www.westerninvestor.com/index.php/news/55-features/764-land-values

Pearce, F. (2012). The land grabbers: The new fight over who owns the earth. London: Beacon Press.

Principles of Responsible Investment (PRI). (2014). The principles of responsible investment in farmland. Retrieved from http://www.unpri.org/areas-of-work/implementationsupport/the-principles-for-responsible-investment-in-farmland/ 
Pritchard, B., Neave, M., Hickey, D., \& Troy, L. (2012). Rural land in Australia: A framework for the measurement and analysis of nationwide patterns of ownership change, aggregation and fragmentation. Canberra, Australia: Government of Australia, Rural Industries Research and Development Corporation.

Rosenbluth, G. (1955). Measures of Concentration. Business Concentration and Price Policy. Ed.: Universities-National Bureau Committee for Economic Research. Princeton: Princeton University Press, 57-99.

Ross, L., \& Mittal, A. (Eds.) (2014). Down on the farm - Wall Street: America’s new farmer. The Oakland Institute. Retrieved from http://www.oaklandinstitute.org/sites/oaklandinstitute.org/files/OI_Report_Down_on_the Farm.pdf

Saskatchewan Bureau of Statistics. ( 2012). Saskatchewan population report: 2011 Census of Canada. Retrieved from http://www.stats.gov.sk.ca/stats/population/Censuspop2011.pdf

Saskatchewan Bureau of Statistics. (2006). Saskatchewan census population. Retrieved from http://www.stats.gov.sk.ca/stats/population/SaskCensusPopulation8106.pdf

SaskWorks. (2011). Annual Report. Retrieved from http://www.saskworks.ca/assets/files/shareholder/2011AnnualReport.pdf

SaskWorks. (2014). Diversified share class. Retrieved from http://www.saskworks.ca/diversified/portfolio.htm

Savills. (2012). International farmland: Focus 2012. Going with the grain: Why international farmland is becoming an increasingly sought after investment. Retrieved from http://pdf.euro.savills.co.uk/global-research/international-farmland-focus.pdf

Sommerville, M. (2013). Financializing prairie farmland: farmland investment funds and the restructuring of family farming system in central Canada. LDPI Working Paper 38. Retrieved from http://www.iss.nl/fileadmin/ASSETS/iss/Research_and_projects/Research_networks/LD PI/LDPI_WP_38.pdf

Sommerville, M., \& Magnan, A. (2015). "Pinstripes on the prairies”: Examining the financialization of farming systems in the Canadian Prairie provinces. Journal of Peasant Studies.

Statistics Canada. (2011a). Tenure of Land owned, Leased, Rented, Crop-Shared, Used Through Other Arrangements or Used By Others, 2011. Retrieved from http://www29.statcan.gc.ca/ceag-web/eng/province-geo-data-selectiongeo ?geoId $=470000000 \&$ selectedVarIds $=82 \% 2 \mathrm{C} 83 \% 2 \mathrm{C} 80 \% 2 \mathrm{C} 81 \% 2 \mathrm{C} 86 \% 2 \mathrm{C} 84 \% 2 \mathrm{C} 85$ \%2C\#export 
Statistics Canada. (2011b). Population and Dwelling Counts, for Canada, Provinces and Territories, and Census Subdivisions, 2011 and 2006 Censuses. Retrieved from http://www12.statcan.gc.ca/census-recensement/2011/dp-pd/hlt-fst/pd-pl/TableTableau.cfm LANG $=$ Eng $\& \mathrm{~T}=302 \& S R=1 \& S=51 \& \mathrm{O}=\mathrm{A} \& \mathrm{RPP}=9999 \& \mathrm{PR}=47 \& \mathrm{CMA}=0$

Statistics Canada. (2014). Table 002-0008 - Farm debt outstanding, classified by lender, annual (dollars), CANSIM (database).

Third World Quarterly. (2013). Global land grabs [Special issue]. 34(9).

UNCTAD. (2014). United Nations Conference on Trade and Development. Principles for responsible agricultural investment. Retrieved from http://unctad.org/en/Pages/DIAE/G20/PRAI.aspx

Vanclief, L. (1998). Notes for an address by the Honourable Lyle Vanclief, Minister of Agriculture and Agri-Food, to the 1998 American Farm Journal Forum, Washington, D.C., Dec. 1. Retrieved from http://www.agpub.on.ca/pc/doc/lv1201.htm

Werklund. (2014). Top Soil. Retrieved from http://www.werklund.com/capital/selectportfolio/top-soil.cfm

White, B., Borras, S., Hall, R., Scoones, I., \& Woolford, W. (2012). The new enclosures: Critical perspectives on corporate land deals. Journal of Peasant Studies, 39(3-4), 619-647.

Wiebe, N. (2012). Crisis in the food system: The farm crisis. In M. Koc, J. Sumner \& A. Winson (Eds.), Critical Perspectives in Canadian Food Studies (pp. 155-170). Don Mills, CA: Oxford University Press.

Wolford, W. (2010, October). Contemporary land grabs in Latin America. Paper presented at the TNI-ICAS-FIAN side event to the $13^{\text {th }}$ session of the FAO World Food Security Council, Rome. Retrieved from https://devsoc.cals.cornell.edu/sites/devsoc.cals.cornell.edu/files/shared/documents/16Contemporary-Landgrabs-in-Latin-America-docx.docx

Zoomers, A. (2010). Globalization and the foreignisation of space: Seven processes driving the current global land grab. Journal of Peasant Studies, 37(2): 429-447. 